\title{
Nutritional, microbial and sensory quality evaluation of fermented Puntius sophore Hamilton, 1822 (Puthi shidal) marketed in North-east India
}

\author{
Bipul Kumar Kakati ${ }^{*}$, Pranjyoti Sarma ${ }^{2}$, Sarifuddin Ahmed ${ }^{2}$ and Umesh Ch. Goswami ${ }^{3}$ \\ ${ }^{1}$ Department of Fisheries Engineering, College of Fisheries, Assam Agricultural University, Raha, Nagaon-782103 \\ (Assam), INDIA \\ ${ }^{2}$ Department of Fish Processing Technology, College of Fisheries, Assam Agricultural University, Raha, Nagaon- \\ 782103 (Assam), INDIA \\ ${ }^{3}$ Department of Zoology, Gauhati University, Guwahati -781014 (Assam), INDIA \\ *Corresponding author: E-mail:bkkakati@gmail.com \\ Received: August 21, 2017; Revised received: October 19, 2017; Accepted: February 5, 2018
}

\begin{abstract}
Biochemical, microbiological and sensory qualities of Puthi shidal from the markets of North-east India were studied. Puthi shidal was found as a good source of protein $(38.35 \%)$. Its $\mathrm{pH}$ and moisture content was found

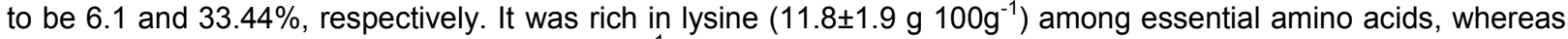

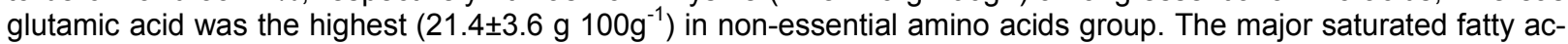
ids were palmitic acid $(14.0 \pm 1.5$ mole $\%)$ and stearic acid $(17.0 \pm 2.3$ mole $\%)$. The oleic acid $(19.1 \pm 1.5$ mole $\%)$ was the prominent monounsaturated fatty acid. The dominant polyunsaturated fatty acids were of the $n-6$ series. The major polyunsaturated fatty acids (PUFA) found chiefly in linoleic acid $(11.0 \pm 1.4$ mole $\%)$ in the sample. The microbial load (log cfu/g) of Puthi Shidal comprised of total plate count $(5.4 \pm 0.35)$, Staphylococcus aureus $(2.4 \pm 0.30)$ and Streptococcus spp. $(1.1 \pm 0.1)$, indicating unhygienic handling practices during preparation and storage. The physicochemical analysis i.e. total volatile base nitrogen (TVB-N) $(116.20 \mathrm{mg} \%)$, non protein nitrogen (NPN) $(2.50 \%)$, peroxide value (PV) (39.12 milliequivalent $\mathrm{O}_{2} / \mathrm{g}$ of fat), free fatty acids (FFA) (64.50\% as oleic acid) and overall acceptability $(6.9 \pm 0.59)$ revealed that the product was of acceptable quality. Though the product was found to have high nutritional value, strict hygienic measures should be adopted right from the preparation of raw materials, processing methods and during storage, in order to safeguard the health of the consumers.
\end{abstract}

Keywords: Amino acids, Fatty acids, Fermentation, Puntius sophore, Puthi shidal

\section{INTRODUCTION}

Fermented Puntius sophore (Hamilton, 1822) is a saltfree traditional fish product with a paste surface, locally known as Puthi Shidal in the northeastern states of India. Puthi Shidal is widely used by the people of the region, because of its flavour and taste. Fisherfolk, tribals and non-tribals (especially Bengali speaking people) use Puthi Shidal as a condiment with their staple food. Shidal is an important component of a popular oil-free preparation known as Godhak in the tribal food culture (Majumdar, 2007). Irombea or Morok Metpa, Paknam, Kangsoi are some of the popular traditional food preparation in Manipur using Shidal/Ngari as an ingredient (Devi and Suresh, 2012). Even though different preservative steps are involved in the curing process, prepared products are found to undergo gradual deterioration as they are usually stored at ambient temperature until consumption. The procedures used for the processing of fermented fish products do not include steps, such as cooking or pas- teurization that destroys pathogens. Barber and Deibel (1972) reported the incidence of staphylococcus food poisoning associated with fermented food, thus causing gastroenteritis in humans. Lien (2002) reported an outbreak of Staphylococcus aureus food poisoning in Nesby in 12 to 22 people who consumed Rakeorret (a fermented fish product).

Puthi shidal was mostly produced in the household/ small-scale factory with limited process control to ensure product quality and safety. It was produced by natural and largely uncontrolled fermentation. In addition, the environment in which the fish was processed was not hygienic, paving the way for possible contamination. Moreover, it was also attributed to the fact that no salt has been added during the preparation of such type of fermented fish product. The packaging of the product was also not up to the mark during marketing. Therefore, the present study was carried out to assess the proximate composition, biochemical, microbiological and sensory qualities of Puthi shidal available in the markets of North-east India. 


\section{MATERIALS AND METHODS}

Preparation of Puthi shidal: For traditional Shidal preparation (Fig.1), the fresh fish species (P. sophore) were allowed to sun-dry for 5-6 days and filled into the airtight earthen pot (locally called Koloh). Dried fishes $(P$. sophore) were soaked in water for 5-10 minutes and allowed to drain the water overnight prior to filling in the earthen pots. Soaking of raw materials is very important in the preparation of Shidal and crucial for obtaining the best quality product. By repeated smearing of oil (fish oil extracted from the entrails of $P$. sophore or other freshwater fishes, through an indigenous crude method or vegetable oil for smearing) and subsequent drying in the sun, the Koloh (round bottomed and narrow necked earthen vats, the capacity of which ranges from $10-40 \mathrm{~kg}$ ) are saturated with oil. Unlike the other fermented fish products, salt is never added during preparation of Shidal. The filled earthen pot is then sealed airtight, thus providing an anaerobic condition inside and stored at room temperature (28$31^{\circ} \mathrm{C}$ ) for 3-4 months for fermentation.

Collection of samples: Puthi shidal was collected from the Jagiroad dry fish market of Assam (one of the largest dry fish markets in Asia), packed in lowdensity polyethylene pouches (thickness: 200gauge) and brought to the laboratory in aseptic condition. The product was stored under ambient conditions $\left(30 \pm 2^{\circ} \mathrm{C}\right)$ for further analyses. The product was procured from the retailers after two days of opening the airtight sealed fermenting containers. The retailers kept the product in plastic containers and in earthen pots before sale. The raw materials used for Shidal preparation, i.e. $P$. sophore was also collected from the local market for quality studies. The fishes were iced and brought to the processing hall in aseptic condition. Both the raw material and the prepared products (Puthi shidal) were analyzed for different quality parameters in triplicate.

Biochemical analysis: Moisture, crude protein, crude fat and ash content of the fish products were determined by AOAC, (2000) methods, standard methods were used for the determination of salt soluble nitrogen (SSN) (Dyer et al., 1950), non protein nitrogen (NPN) (AOAC, 2000), total volatile base nitrogen (TVB-N) (Conway, 1947), peroxide value (PV) (Jacobs, 1958), free fatty acids (FFA) (Olley and Loveren, 1960). pH was determined using a $\mathrm{pH}$ meter (Sartorius Make), after homogenizing $5 \mathrm{~g}$ of the fish sample with $45 \mathrm{ml}$ distilled water. Amino acid compositions of fresh fish and Puthi Shidal were determined by the methods of Chang et al., 1991 and Sastry and Tummuru, 1985. The fatty acid compositions were determined by fatty acid methyl ester (FAME)/gas chromatography using acetyl chloride as a reagent for transesterification according to the method of Christie (1993).

Microbiological and sensory analysis: An amount of $10 \mathrm{~g}$ of muscle from different parts of the sample was collected aseptically and macerated with $90 \mathrm{ml}$ sterile saline. The microbial quality of the samples was determined after making two serial dilutions in the same diluents. The microbial quality of Puthi Shidal was determined by the methods of APHA (2001).

Sensory evaluation of the sample was carried out using the 9- point hedonic scale by a trained taste panel consisting of 10 members. The sensory quality of Puthi Shidal sample was judged for appearance, colour, texture, flavour intensity and overall acceptability. The colour was recorded, based on visual observation and texture by applying pressure by the finger tips (Lilabati et al., 1999).

Statistical analysis was done by performing one way ANOVA to compare the means at 5\% level using SPSS 16.0 software (SPSS for Windows. Release 11.5. Chicago: IL: SPSS Inc, 2005).

\section{RESULTS AND DISCUSSION}

The proximate composition and biochemical quality parameters of $P$. sophore used for Shidal preparation are shown in Table 1. The mean value of moisture, crude protein, crude fat and ash were found to be $66.70 \%, 20.80 \%, 6.90 \%$ and $4.90 \%$, respectively. The $\mathrm{pH}$ value of the fresh fish sample was 7.1. The salt soluble nitrogen was $71.30 \%$ of total protein. The nonprotein nitrogen and total volatile base nitrogen content of the fish was $60 \mathrm{mg} \%$ and $1.90 \mathrm{mg} \%$, respectively. The peroxide value and free fatty acid was 12.60 milliequivalent $\mathrm{O}_{2} / \mathrm{g}$ of fat and $33.70 \%$ as oleic acid, respectively. All the results obtained were within acceptable limits. Hence it revealed that $P$. sophore available in the markets was found to be of a highly nutritious and fresh quality. Similar results were recorded in case of $P$. sophore collected from natural resources of Tripura (Karthikeyan et al., 2007).

The mean value of moisture, crude protein, crude fat and ash of Puthi Shidal are presented in Table 2. The moisture content of Puthi Shidal was $33.44 \%$. The

Table 1. Quality of raw material (Fresh Puntius sophore) used for preparation of shidal

\begin{tabular}{ll}
\hline Parameters n=3 & Fresh Puntius sophore \\
\hline Length $(\mathrm{Cm})$ & $8.2 \pm 1.30$ \\
Weight $(\mathrm{g})$ & $11.0 \pm 2.50$ \\
Moisture, \% & $66.7 \pm 0.89$ \\
Crude protein, \% & $20.8 \pm 0.66$ \\
Crude fat, \% & $6.9 \pm 0.43$ \\
Ash, \% & $4.9 \pm 0.72$ \\
pH & $7.1 \pm 0.01$ \\
Salt soluble nitrogen, & $71.3 \pm 1.35$ \\
(\% of total N) & \\
Non protein nitrogen, (mg \%) & $60 \pm 0.11$ \\
Total volatile base N, (mg \%) & $1.9 \pm 0.20$ \\
Peroxide value (milliequivallent & $12.6 \pm 2.10$ \\
$\mathrm{O}_{2} / \mathrm{g}$ of fat) & \\
Free fatty acids (\% as oleic acid) & $33.7 \pm 1.41$ \\
\hline
\end{tabular}

All values are mean \pm standard deviation 
Table 2. Quality of Puthi shidal available in the markets of North east India

\begin{tabular}{ll}
\hline Parameters N=3 & Puthi shidal \\
\hline Moisture, \% & $33.44 \pm 0.88$ \\
Crude protein, \% & $38.35 \pm 1.67$ \\
Crude fat, \% & $20.31 \pm 0.42$ \\
Ash, \% & $7.19 \pm 0.12$ \\
$\mathrm{pH}$ & $6.1 \pm 0.03$ \\
Salt soluble nitrogen, $(\%$ of total N) & $40.70 \pm 0.98$ \\
Non protein nitrogen, $\mathrm{mg} \%$ & $2.50 \pm 0.21$ \\
Total volatile base $\mathrm{N}, \mathrm{mg} \%$ & $116.20 \pm 0.77$ \\
Peroxide value (milliequivallent $\mathrm{O}_{2} / \mathrm{g}$ of & $39.12 \pm 0.98$ \\
fat) & \\
Free fatty acids $(\%$ as oleic acid) & $64.50 \pm 0.67$ \\
Total plate count $(\log \mathrm{cfu} / \mathrm{g})$ & $5.4 \pm 0.35$ \\
Yeast and mould $(\log \mathrm{cfu} / \mathrm{g})$ & $1.7 \pm 0.20$ \\
Staphylococcus aureus $(\log \mathrm{cfu} / \mathrm{g})$ & $2.4 \pm 0.30$ \\
Escherichia coli $(\log \mathrm{cfu} / \mathrm{g})$ & $<1$ \\
Streptococcus spp. $(\log \mathrm{cfu} / \mathrm{g})$ & $1.1 \pm 0.1$ \\
Salmonella spp. (log cfu/g) & Absent \\
Appearance & $6.9 \pm 0.79$ \\
Colour & $6.5 \pm 0.98$ \\
Texture & $6.7 \pm 1.30$ \\
Flavour intensity & $7.1 \pm 0.88$ \\
Overall acceptability & $6.9 \pm 0.59$ \\
\hline All values are mean \pm standard &
\end{tabular}

All values are mean \pm standard deviation

moisture content of Chepa Shutki, a semi-fermented fishery product prepared from Puntius spp. collected from the markets of Bangladesh was in ranges from 39.62 to $46.89 \%$ (Nayeem et al., 2010). The high value of moisture content in Shidal might be due to the possible absorption of moisture from the environment during storage, since in most places Shidal was stored in earthen pots or in plastic bottles during marketing. A similar reason was reported for the high moisture content of fermented Setipinna phasa (Phassya shidal) stored in earthen pots in the markets of Assam, India (Kakati and Goswami, 2017).The present study revealed that the moisture content was within the range of the BIS standard, which prescribed a range of 10$35 \%$ for smaller fish and $40-45 \%$ for bigger ones (Gopakumar and Devadasan, 1982). The $\mathrm{pH}$ value of Puthi Shidal sample was 6.1. The mean value of moisture and $\mathrm{pH}$ of the sample indicates that the Shidal was a stable product.

The protein content was $38.35 \%$. The protein content of semi fermented fish product (Chepa shutki) collected from retailer, wholesaler and producer was reported

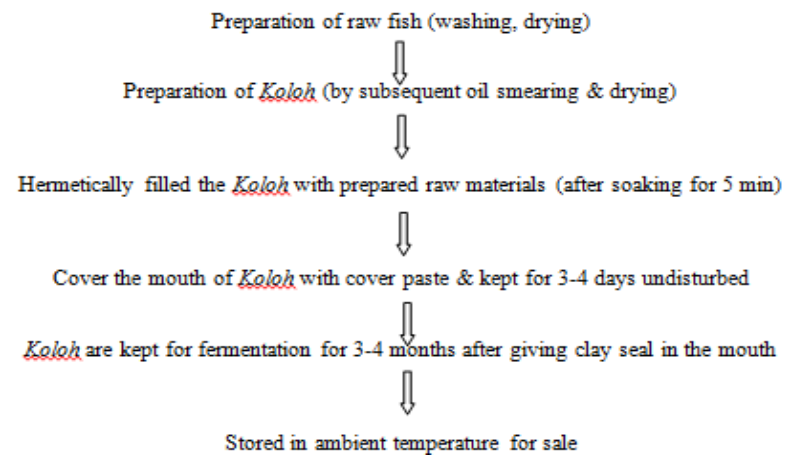

Fig.1. Preparation of Shidal by traditional method
Table 3. Amino acid composition (g amino acid per $100 \mathrm{~g}$ of protein) of fresh Puntius sophore and Puthi shidal.

\begin{tabular}{llll}
\hline $\begin{array}{l}\text { Amino acids (gm } \\
\mathbf{1 0 0}_{\text {gm }^{-1} \text { ) N=5 }}\end{array}$ & $\begin{array}{l}\text { Fresh Puntius } \\
\text { sophore }\end{array}$ & $\begin{array}{l}\text { Puthi } \\
\text { shidal }\end{array}$ & P value \\
\hline Essential amino & & & \\
acids & & & \\
\hline Arginine & $5.8 \pm 1.0$ & $6.0 \pm 1.1$ & 0.827 \\
Histidine & $2.0 \pm 0.5$ & $2.2 \pm 0.6$ & 0.680 \\
Isoleucine & $3.4 \pm 0.2$ & $3.7 \pm 0.3$ & 0.223 \\
Leucine & $8.3 \pm 0.5$ & $8.9 \pm 1.2$ & 0.542 \\
Lysine & $11.5 \pm 1.5$ & $11.8 \pm 1.9$ & 0.841 \\
Methionine & $1.9 \pm 0.4$ & $2.1 \pm 0.2$ & 0.125 \\
Phenyl analine & $3.7 \pm 0.3$ & $3.9 \pm 0.8$ & 0.368 \\
Threonine & $4.5 \pm 0.5$ & $4.5 \pm 0.7$ & 1.000 \\
Valine & $5.2 \pm 1.3$ & $5.6 \pm 0.3$ & 0.552 \\
Tryptophan & $1.4 \pm 0.1$ & $1.8 \pm 0.2$ & 0.081 \\
\hline Non essential & & & \\
\hline Aspartic acid & $9.5 \pm 0.7$ & $9.6 \pm 0.9$ & 1.000 \\
Aspergine & $4.2 \pm 0.4$ & $5.5 \pm 0.6$ & $0.035 *$ \\
Alanine & $6.2 \pm 1.2$ & $6.8 \pm 1.4$ & 0.663 \\
Cystein & $0.8 \pm 0.2$ & $1.0 \pm 0.3$ & 0.391 \\
Glutamic acid & $21.0 \pm 2.3$ & $21.4 \pm 3.6$ & 0.849 \\
Glycine & $4.6 \pm 1.2$ & $4.8 \pm 0.8$ & 0.656 \\
Proline & $4.4 \pm 0.5$ & $4.9 \pm 1.0$ & 0.196 \\
\hline
\end{tabular}

Mean value \pm standard deviation

as $61.71 \%, 58.26 \%$ and $65.75 \%$ (on dry weight basis), respectively (Azam et al., 2003).

The content of SSN $(40.70 \%$ of total N), NPN $(2.50$ $\mathrm{mg} \%)$ and TVB-N (116.20 $\mathrm{mg} \%)$ of the sample indicates the degradation of tissue protein that may be responsible for the generation of the typical flavor and aroma of Puthi Shidal (Table 2). The high value of NPN and TVB-N might be attributed to the subsequent microbiological and biochemical changes in the fish muscle during the drying and fermentation process. The value of NPN and TVB-N of salt fermented Lona ilish were reported as $540 \mathrm{mg} \%$ and $48 \mathrm{mg} \%$, respectively (Majumdar et al., 2005).

The amino acids composition of a fish product contributes significantly to its taste and also decides the quality of the protein. Glycine, alanine, serine and threonine taste sweet, while arginine, leucine, valine, phenyl alanine, histidine and isoleucine give a bitter taste (Sikorski and Kolakowska, 1990). The amino acids

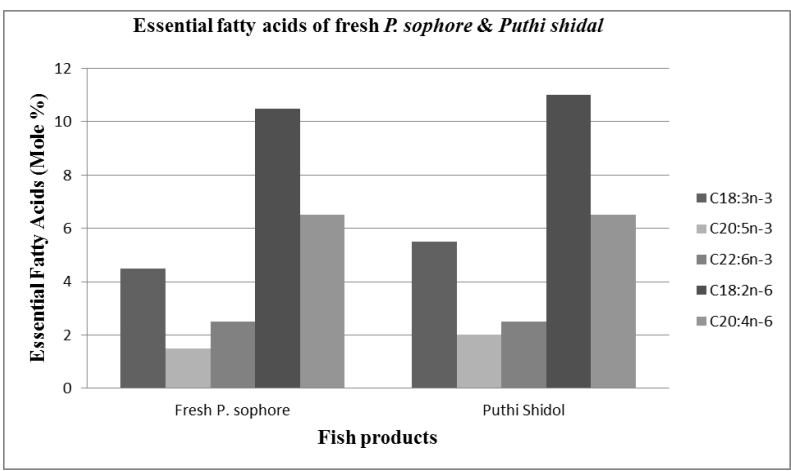

Fig. 2. Essential fatty acids of fresh P. sophore and Puthi shidal 
Table 4. Fatty acids composition of fresh Puntius sophore and Puthi shidal.

\begin{tabular}{llll}
\hline $\begin{array}{l}\text { Fatty acids com- } \\
\text { position } \\
\text { (mo5 }\end{array}$ & $\begin{array}{l}\text { Fresh Pun- } \\
\text { tius sophore }\end{array}$ & $\begin{array}{l}\text { Puthi } \\
\text { shidal }\end{array}$ & $\begin{array}{l}\text { P } \\
\text { value }\end{array}$ \\
\hline Saturated & & & \\
\hline C12:0 & $0.4 \pm 0.01$ & $0.5 \pm 0.2$ & 0.436 \\
C14:0 & $3.5 \pm 0.5$ & $3.6 \pm 0.5$ & 1.000 \\
C15:0 & $1.6 \pm 0.2$ & $1.8 \pm 0.4$ & 0.125 \\
C16:0 & $13.5 \pm 1.0$ & $14.0 \pm 1.5$ & 0.656 \\
C17:0 & $2.3 \pm 0.3$ & $2.4 \pm 0.6$ & 0.633 \\
C18:0 & $16.4 \pm 1.5$ & $17.0 \pm 2.3$ & 0.768 \\
C19:0 & $1.0 \pm 0.3$ & $1.0 \pm 0.5$ & 1.000 \\
\hline Mono unsaturated & & & \\
\hline C16:1 n-7 & $7.4 \pm 0.5$ & $7.9 \pm 1.7$ & 0.651 \\
C18:1 n-3 & $18.6 \pm 1.5$ & $19.1 \pm 1.5$ & 0.704 \\
C20: 1 & $1.0 \pm 0.2$ & $1.5 \pm 0.2$ & $0.038^{*}$ \\
C22:1 & ND & ND & ND \\
\hline PUFA & & & \\
\hline C18:2n-6 & $10.7 \pm 0.8$ & $11.0 \pm 1.4$ & 0.620 \\
C18:3n-3 & $4.6 \pm 0.5$ & $5.4 \pm 0.5$ & 0.070 \\
C18:4n-3 & $1.5 \pm 0.2$ & $2.1 \pm 0.2$ & $0.038^{*}$ \\
C20:4n-6 & $6.4 \pm 0.5$ & $6.5 \pm 1.3$ & 1.000 \\
C20:5n-3 & $1.5 \pm 0.2$ & $2.0 \pm 0.2$ & $0.038^{*}$ \\
C22:5n-3 & $0.4 \pm 0.01$ & $0.5 \pm 0.02$ & 1.000 \\
C22:6n-3 & $2.4 \pm 0.4$ & $2.5 \pm 0.3$ & 1.000 \\
Unidentified & $6.8 \pm 0.4$ & $1.2 \pm 0.07$ & 0.114 \\
\hline
\end{tabular}

Mean value \pm standard deviation, Fatty acids are represented in the following manner: the first number indicates the number of carbons, while the second represents the number of double bonds. ND: not detectable.

composition of fresh P. sophore and Puthi Shidal is presented in Table 3. Each amino acid content was increased during fermentation, but the fermentation effect on amino acids composition of the sample was not significant except in aspargine $(\mathrm{P}<0.05)$. The increase in the level of each free amino acid during fermentation appeared to be attributable to the results of a dynamic balance between the production and breakdown of free amino acids by autolysis and microbial action and the degradation of some muscle proteins into peptides and amino acids. Chang et al., (1994) reported that the contents of free amino acid, especially glutamic acid, alanine, valine and leucine were increased during the fermentation of Hatahata-zushi, a Japanese fermented product of sand-fish and boiled rice. Puthi Shidal and fresh $P$. sophore were rich in lysine, leucine, valine, aspartic acid, alanine and glutamic acid. Lysine was the most abundant among the essential amino acids, whereas glutamic acid was found to be higher in the non-essential amino acids group. Rabie et al., (2009) observed that the predominant free amino acids were leucine, glutamic acid, lysine, alanine, valine, aspartic acid, isoleucine and citrulline in an Egyptian salted-fermented fish product (Feseekh) during ripening. Dincer et al., (2010) also reported the high amounts of glutamic acid, alanine, lysine, leucine and aspartic acid in fish sauce, produced by incubating mixtures of sardine (Sardina pil-
Table 5. Major fatty acids class of fresh Puntius sophore and Puthi shidal.

\begin{tabular}{llll}
\hline $\begin{array}{l}\text { Fatty acids composi- } \\
\text { tion }\end{array}$ & $\begin{array}{l}\text { Fresh } \boldsymbol{P} . \\
\text { sophore }\end{array}$ & $\begin{array}{l}\text { Puthi } \\
\text { shidal }\end{array}$ & $\begin{array}{l}\text { \% } \\
\text { Change }\end{array}$ \\
\hline Saturated fatty acid & 38.70 & 40.30 & 4.13 \\
$\begin{array}{l}\text { Mono unsaturated fatty } \\
\text { acids }\end{array}$ & 27.00 & 28.50 & 5.56 \\
$\begin{array}{l}\text { Poly unsaturated fatty } \\
\text { acids }\end{array}$ & 27.50 & 30.00 & 9.09 \\
\hline
\end{tabular}

chardus) at 6 different concentrations of sodium chloride and glucose at $37^{\circ} \mathrm{C}$ for 57 days.

Lipid is an important constituent, determining both functionality and sensory properties of processed fish products. Depending on the content, composition and properties, lipids as well as their fatty acids, contribute to a wide range of quality attributes. The changes in lipid during processing, such as lipolysis and lipid oxidation, have a major impact, both desirable and deleterious for the final product quality of meat products (Visessanguan et al., 2006).

The PV and FFA of Puthi Shidal were found to be 39.12 milliequivalent $\mathrm{O}_{2} / \mathrm{g}$ of fat and $64.50 \%$ of oleic acid, respectively (Table 2). The PV is a measure of the first stage of oxidative rancidity, and fish lipid being highly unsaturated, is highly liable for both autolytic as well as oxidative rancidity (Balachandran, 2001). Though the Shidal fermentation is an anaerobic/micro aerophilic process, higher values of PV of the market samples might be attributed to direct exposure to air during retailing, resulting in the lipid oxidation of the product. Oxidation of lipids is of economic and nutritional significance to the food industry as well as to consumers. It may result in sensory changes (flavour and aroma) and loss of nutritional value (essential fatty acids, fat-soluble vitamins: A, D, E, K), production of primary and secondary oxidation products (hydroperoxides, free radicals, epoxides) etc. A similar PV (41.3 millimoles/gm of fat) and FFA (31.84\% oleic acid) has been reported in salted anchovy after 9 weeks of fermentation (Hernandaz-Herrero et al., 1999). The PV and FFA value for Lona ilish, a traditional salt fermented fish product of northeast India were also recorded as 40.0 meq $\mathrm{O}_{2} / \mathrm{kg}$ of fat and $18.22 \%$ oleic acid, respectively (Majumdar and Basu, 2010).

The fish oils of fresh P. sophore and Puthi Shidal are unique in the variety of fatty acids (Table 4) of which they are composed and their degree of unsaturation (Table 5). The nature, proportion and degree of unsaturation of the fatty acids in the lipids are all closely related to the oxidation of the oils (Ugoala et al., 2008).

The fatty acids profiles of fresh fish and Puthi Shidal (Table 4) included minor amounts of odd-number and even-number fatty acids. The mole percent of each fatty acid seemed to vary. An increase in the contents of the fatty acids composition was observed in the Puthi Shidal during fermentation. Significant variations $(\mathrm{P}<0.05)$ in the proportions of some unsaturated 
fatty acids were noticed between product and fresh fish. The changes observed in the lipid composition may be attributed to the lipolysis of both triacylglycerol and phospholipid during fermentation. The lipolytic activity during fermentation might be due to lipases of both the muscular tissue and microbial origin (Toldra and Flores, 1998). Visessanguan et al., (2006) also reported that fatty acids contents in both total and nonpolar lipid fractions was increased during fermentation, in the case of Nham, a Thai fermented pork sausage.

The saturated fatty acids (SFA), monounsaturated fatty acids (MUFA) and polyunsaturated fatty acids (PUFA) of fresh P. sophore and Puthi Shidal was 38.7\%, $27.0 \%, 27.5 \%$ and $40.3 \%, 28.5 \%, 30.0 \%$, respectively (Table 5). The total SFA content of lipids was reported to be $41.8 \%$ in Spanish mackerel, $45.74 \%$ in Grouper and $41.09 \%$ in Yellow-spotted Trevally. The high value of SFA recorded in both the samples of the present study were palmitic acid (C16:0) and stearic acid (C18:0). The higher amount of palmitic acid in tuna meat had been also reported by Nimish et al., (2010).

Oleic acid (C18:1) is the prominent monounsaturated fatty acid observed in both the samples studied. In the samples analyzed, the dominant PUFA are of the n-6 series in fresh P. sophore and Puthi Shidal. The major PUFA found chiefly in linoleic acid (C18:2) in both fresh fish and Shidal. Due to high susceptibility to chemical and enzymatic oxidation, polyunsaturated fatty acids possibly act as precursors for flavour development during fermentation (Josephson, 1991). The samples studied contain all the essential fatty acids, although they vary in composition (Fig. 2). The major n-3 polyunsaturated fatty acids observed in lipids were eicosapetanoic acid (20:5n-3) and docosahexanoic acid $(22: 6 n-3)$ in lower concentration and linolenic acid (18:3n-3) in higher concentration in both fresh fish and Shidal. Among n-6 fatty acids, linoleic acid (18:2n-6) and arachidonic acid (20:4n-6) were dominant. Docosahexanoic acid (DHA) has well-documented health benefits as it is known to reduce the risk of cardiovascular disease, hypertension, autoimmune and inflammatory diseases (Kim and Mendis, 2006).

The samples were analyzed for pathogenic contamination. The determination of standard plate count, the faecal coliform count and Staphylococcus count are the widely accepted parameters in the inspection of fish food (Anon, 1964). Pathogenic contaminants like Staphylococcus aureus, Streptococcus spp. and Escherichia coli were detected in the Puthi Shidal sample. The count of $S$. aureus and Streptococcus spp. were $2.4 \log \mathrm{cfu} / \mathrm{g}$ and $1.1 \mathrm{log} \mathrm{cfu} / \mathrm{g}$, respectively, whereas the number of E. coli was less than $1.0 \mathrm{log} \mathrm{cfu} / \mathrm{g}$. Salmonella spp. were not detected. The presence of $S$. aureus, Streptococcus spp. and E. coli in fermented fish products might be attributed to poor handling practices and faecal contamination during processing and storage (ICMSF, 1996). S. aureus was regarded as a poor competitor and its growth in fermented food is generally associated with a failure of the normal microflora (Nychas and Arkoudelos, 1990). The growth of Staphylococcus in food presents a potential health hazard since many strains produce enterotoxins, which cause food poisoning if ingested. Barber and Deibel, (1972) reported the incidence of Staphylococcus food poisoning associated with fermented food causing gastroenteritis in humans. Lien, (2002) reported an outbreak of Staphylococcus aureus food poisoning in Nesby, in 12 to 22 people who consumed Rakeorret (a fermented fish product). In the case of naturally fermented Cassava fish, Bacillus spp. and Staphylococcus spp. were the predominant genera which accounted for $48.7 \%$ and $27.3 \%$ of the total number of isolates, respectively (Anihouvi, 2007). The total plate count of the Puthi Shidal was $5.4 \log \mathrm{cfu} / \mathrm{g}$. There was no visible fungal colony on the products. However, when grown on agar medium, a few yeast and mould colonies (1.7 log cfu/g) were observed. Similar results were also reported from Nam-pla and Kapi (Watanaputi et al., 1983). The growth of spoilage/ pathogenic bacteria and contamination can be prevented by the control of hygiene, sanitation and water quality.

The sensory quality of Puthi Shidal was studied and is presented in Table 2 . The sensory attributes evaluated for Puthi Shidal revealed that the product had a good sensory quality and overall acceptability. Though the product was found to have the satisfactory appearance (6.9), colour (6.5) and texture (6.7), yet the overall acceptability of the product depends mainly on the intensity of the flavour (7.1) of Shidal. The complex interaction of enzymatic activity and oxidation during the fermentation, along with the bacterial production of volatile fatty acids may be responsible for the characteristic flavour and aroma of fermented fish products (Beddows et al., 1980). The significant role of bacteria and muscle bacterial proteases in the process of fermentation, flavour and aroma producing process was recorded (Thongthai and Siriwongpairat, 1990). Puthi Shidal had a shiny appearance, with silvery grey colour, characterized by good odour, with a firm and flexible texture. The overall acceptability (6.9) of the sample was graded as acceptable for human consumption.

\section{Conclusion}

The present study revealed that the traditional salt-free fermented fish product Puthi Shidal available in the markets of the Northeastern states of India had a high nutritive value as its protein, fat and ash content were observed to be high. The physicochemical quality of Puthi Shidal was found to be within the acceptable limit. Puthi Shidal could serve as a significant source of essential amino acids. The overall significance of 
this study is the revelation that Puthi Shidal is a good source of polyunsaturated fatty acids, particularly of n6 series of essential fatty acids and contains good amounts of eicosapetanoic acid (EPA) and docosahexanoic acid (DHA). The market sample of Puthi Shidal was contaminated with several pathogens, which are generally associated with public health hazards. Though the absence of Salmonella spp. was a good sign for consumers, yet the aspect of the importance of the public health of the above findings could not be ignored. Therefore, it is stressed that strict hygienic measures should be adopted right from the preparation of raw materials, use of utensils, handling practices, processing methods and during storage, in order to safeguard the health of the consumers.

\section{ACKNOWLEDGEMENTS}

The authors gratefully acknowledge Dr. K. Bhaskarachary, National Institute of Nutrition, Hyderabad, India for his critical discussion for estimation of amino acids and fatty acids composition of fresh Puntius sophore and Puthi shidal. Thanks are due to the cooperation received from the fishing community of Nagaon district, Assam for providing information on traditional preparation and preservation methods of Shidal.

\section{REFERENCES}

Anihouvi, V.B., Sakyi-Dawson, E., Ayernor, G.S. and Hounhouigan, J.D. 2007. Microbiological changes in naturally fermented Cassava fish (Pseudotolithus spp.) for Lauhouin production. Int. J. Food Microbiol. 16 (2):287-291.

Anon. 1964. An evaluation of public health hazards from microbiological contamination of food. Publication 1195, National academy of sciences, National Research Council, Washington, DC.

AOAC. 2000. Official Methods of Analysis, $17^{\text {th }}$ Ed., Association of Official Analytical Chemicals, Washington, D.C., USA.

APHA. 2001. Compendium of methods for the Microbiological Examination of foods. Speak, M. L. (Ed), American Public Health Association Inc, New York.

Azam, K., Basher, M.Z., Ali, M.Y., Asaduzzaman, M. and Hossain, M.M. 2003. Comparative study of organoleptic, microbiological and biochemical qualities of four selected dried fish in summer and winter. Pakistan $J$ Bio. Sci. 6(24): 2030-2033

Balachandran, K.K. 2001. Fermented products. In: PostHarvest technology of fish and fishery products. Daya Publishing House, Delhi, India. pp. 146-157.

Barber, L.E. and Diebel, R.H. 1972. Effect of pH and oxygen tension on Staphyloccal growth and enterotoxin formation in fermented sausage. Applied Microbiol. pp. 891-898.

Beddows, C.G., Ardeshir, A.G. and Daud, W.J. 1980. Development and origin of volatile fatty acids in Budu. J. Sci. Food Agric. 31:86- 92.

Chang, C.M., Ohshima, T. and Koizumi, C. 1991. Lipid free amino acid and organic composition of rice branfermented sardine. Nippon Suisan Gakkaishi, 57: 1579-
1585.

Chang, C.M., Ohshima, T. and Koizumi, C. 1994. Changes in the composition of five amino acids, organic acids and lipids during processing and ripening of 'HatahataZushi', a fermented fish product of sandfish (Arctoscopus japonicus) and boiled rice. J. Sci. Food Agric. 66(1): 75-82.

Christie, W.W. 1993. Preparation of ester derivatives of fatty acids for chromatographic analysis, In: Advances in lipid methodology-two, Dundee: Oily Press. Christie, W. W. (Ed.). pp. 69-111.

Conway, E.J. 1947. Micro diffusion Analysis and Volumetric Error, Crossby, Lockwood and Sons, London.

Devi, P. and Suresh, K.P. 2012. Traditional, ethnic and fermented foods of Manipur. Ind. J. Tradit. Knowle. 11(1): $70-77$.

Dincer, T., Cakli, S., Kilinc, B. and Tolasa, S. 2010. Amino acids and fatty acids composition content of fish sauce. J. Animal Vety. Adv. 9(2): 311-315.

Dyer, F.V. and Snow, J.M. 1950. Proteins in fish muscle Extraction of protein fraction in flesh. J. Fish. Res. 7: 585-593.

Gopakumar, K. and Devadasan, K. 1982. The fish curing industry in India. In: The production and storage of dried fish. James, D. (Ed.). FAO Fisheries Report- 279. pp. 63-68.

Hernandaz-Herrero, M.M., Roig-Saugues, A.X., LopezSabater, E.I., Rodriguez, J.J. and Mora-Ventura, M.T. 1999. Total volatile basic nitrogen and other physiochemical and microbiological characteristics as related to ripening of salted anchovies. J. Food Sci. 64(2): 344347.

ICMSF. 1996. Microbiological specifications of food pathogens. Roberts Baird, T. A., Parker, A. C. and Tompkin, R. B. (Eds). Blackie Academic and Professional, U.K.

Jacobs, M.B. 1958. The chemical analysis of foods and food products. New York Krieger Publishing Co. Inc., USA, p. 393-394.

Josephson, D.B. 1991. Seafood, In: Volatile compounds in food and Beverages. Maarse, H. (Ed.). Marcel Dekker, Inc. New York. pp. 179-202.

Kakati, B.K. and Goswami, U.C. 2017. Nutritional, microbial and sensory quality evaluation of fermented Setipinna phasa, Hamilton 1822, (Phassya Shidal), marketed in North-east India. J. Applied Natural Sci. 9 (1): 237- 244.

Karthikeyan, M., Dhar, B. and Kakati, B.K. 2007. Quality of dried freshwater fish products of commerce in Tripura. J. Food Sci. Technol. 44 (2):161-164.

Kim, S.K. and Mendis, E. 2006. Bioactive compounds from marine processing by-products-A review. Food Res. Int. 39: 383-393.

Lien, A. 2002. Staphylococcus aureus food poisoning after consumption of Rakefish. Norsk Veterinaetidsskrif. 111 (4): $255-257$

Lilabati, H., Vishwanath, W. and Singh, M.S. 1999. Changes in bacterial and fungal quality during storage of smoked Esomus danricus of Manipur. Fish. Technol. 36(1): 3639.

Majumdar, R.K. 2007. Phassya Shidal- A traditional fermented fish product of NE India. Fishing Chimes. 27(5): 30-31.

Majumdar, R.K., Basu, S. and Anandan, R. 2005. Biochemical and microbiological characteristics of salt fermented 
Hilsa (Tenualosa ilisha). Fish Technol., 42 (1): 67-70.

Majumdar, R. K. and Basu, S. 2010. Characteristics of the traditional fermented fish product Lona ilish of Northeast India. Indian. J. Tradit. Knowle. 9(3):453- 458.

Nayeem, M. A., Pervin, K., Reza, M. S., Khan, M. N. A., Islam, M. N. and Kamal, M. 2010. Quality assessment of traditional semi fermented fishery product (Chepa Shutki) of Bangladesh collected from the value chain. Bangladesh Res. Pub. J. 4(1): 41-46.

Nimish, M.S., Jeya, S.R., Jeyasekaran, G. and Sukumar, D. 2010. Effect of different types of heat processing on chemical changes in tuna. J. Food Sci. Technol. 47: 174 -181 .

Nychas, G. J. E. and Arkoudelos, J. S. 1990. Staphylococci: their role in fermented Sausages. J. Appl. Bateriol. 19: $167 \mathrm{~s}-188 \mathrm{~s}$.

Olley, T. and Loveren, J. A. 1960. Phospholipids hydrolysis of cod flesh stored at various temperatures. J. Sci. Food Agric. 11(11): 644-652.

Rabie, M., Simon-Sarkadi, L., Siliha, H., El-Seedy, S. and El -Badaway, A. A. 2009. Changes in free amino acids and biogenic amines of Egyptian salt fermented fish (Feseekh) during ripening and storage. Food Chem. 115 (2):635-638.

Sastry, C. S. P. and Tummuru, M. K. 1985. Spectro photometric determination of tryptophan in protein. J. Food Sci. Technol. 22: 146-147.
Sikorski, Z. E. and Kolakowska, A. 1990. Freezing of marine foods, In: Seafood: Resources, Nutritional composition and Preservation. Sikorski, Z. E. (Ed.). CRC Press, Inc Florida. pp. 112-124.

Thongthai, C. and Siriwongpairat, M. 1990. The sequential quantitization of microorganisms in traditionally fermented fish sauce (Nam-pla). In: Postharvesttechnology, preservation and quality of fish in Southeast Asia. Reilu, P.J.A., Parry, R.W.H., Barlie, L.E. (Eds.). International Foundation of Science Stockholm. pp. 51-59.

Toldra,' F. and Flores, M. 1998. The role of muscle proteases and lipases in flavor development during the processing of dry-cured ham. Crit. Rev. Food Sci. 38: 331352.

Ugoala, C., Ndukwe, G.I. and Audu, T.O. 2008. Comparison fatty acids profile of some fresh water and marine fishes. Internet J. Food Safety. 10: 9-17.

Visessanguan, W., Benjaku,1 S., Riebroy, S., Yarchai, M. and Tapingkae, W. 2006. Changes in lipid composition and fatty acid profile of Nham, a Thai fermented pork sausage, during fermentation. Food Chem. 94: 580 588.

Watanaputi, S.P., Chanyavongse, R., Tubplean, S., Tanasuphratana, S. and Srimahasongkhraam, S. 1983. Microbiological analysis of Thai fermented foods. J. Graduate School, Chulalongkorn University. 4:11-24 